\title{
ALLERGIC MANIFESTATIONS OF PRIMARY IMMUNODEFICIENCY DISEASES AND ITS TREATMENT APPROACHES
}

\author{
OKSANA BOYARCHUK* \\ Department of Children's Diseases and Pediatric Surgery, I. Horbachevsky Ternopil State Medical University, Ternopil City, Ukraine. \\ Email: boyarchuk@tdmu.edu.ua
}

Received: 11 August 2018, Revised and Accepted: 27 September 2018

\begin{abstract}
Allergic manifestations are one of the clinical signs of primary immunodeficiency diseases (PID). In this review, the common allergic manifestations of PID are summarized, and their main differential characteristics and treatment approaches are outlined. Allergic manifestations occur more often in patients with combined immunodeficiencies with or without associated or syndromic features. In patients with PID they usually are present in the $1^{\text {st }}$ year of life, may be among the first symptoms of PID, and are commonly manifested by eczema and increased immunoglobulin IgG levels. Often the skin barrier function is not impaired in patients with eczema and PID, although some diseases (such as Comel-Netherton syndrome) do affect skin barrier function. There is usually no correlation between IgE levels and the severity of allergic skin manifestations. Allergic-like manifestations in PID patients include urticaria-like rash and angioedema. Urticaria-like rash is associated with autoinflammatory disorders, which are commonly accompanied by fever, and caused by a neutrophilic infiltrate in the dermis. Angioedema in hereditary angioedema patients is caused by high bradykinin production. Early differentiation of allergic manifestations in PID from atopic dermatitis and other atopic conditions is very difficult; however, it is very important because it influences on treatment methods. A multidisciplinary approach to the management of PID patients, with the involvement of immunologists, allergists, and formulation of appropriate treatment improve the prognosis and quality of life of the PID patients.
\end{abstract}

Keywords: Allergic manifestations, Primary immunodeficiencies, Treatment approaches.

(C) 2018 The Authors. Published by Innovare Academic Sciences Pvt Ltd. This is an open access article under the CC BY license (http://creativecommons. org/licenses/by/4. 0/) DOI: http://dx.doi.org/10.22159/ajpcr.2018.v11i11.29059

\section{INTRODUCTION}

Primary immunodeficiency diseases (PID) are a group of disorders caused by genetic defects in the immune system that leads to immune dysfunction [1]. The most frequent manifestations of PID are severe recurrent infections that are caused by unusual organisms and are difficult to cure [2,3]. Among other manifestations of PID, there are autoimmune diseases, allergic disorders, and malignancy.

Allergic disorders are often manifested by atopy, which typically can be present as atopic dermatitis (eczema), allergic rhinitis (hay fever) or asthma. The majority of allergic diseases are immunoglobulin $\operatorname{IgE}$ mediated [4]. At present, almost half of the world's population suffers from allergic diseases. The prevalence of allergic disorders has rapidly increased in recent years but is significantly underdiagnosed in some countries [5].

In patients with the normal function of the immune system, infections lead to Th1 and Th2 type of immune responses. This also causes the development of Tregs, which support a balance between Th1 and Th2 immune responses, and prevent their harmful effects. In the cases of absent or poor Tregs check, the patients become more susceptible to allergic or autoimmune disorders [4].

Physicians' awareness concerning PID is poor among physicians of different specialties [6], though an early diagnosis of these diseases is very important for preventing the development of complications and improving the quality of life of the children with PID. Allergic manifestations of skin are often early findings of PID [7]. Thus, it is very important to recognize allergic reactions as possible manifestations of PID.

The purpose of this study was to collect and systematize data on PID, associated with allergic or allergic-like manifestations for improving the early diagnosis of PID.

The novelty of the study is in the complex assessment of allergic and allergic-like manifestations in children with PID.

\section{ALLERGIC MANIFESTATIONS OF PID}

PID are classified into nine major groups: Combined immunodeficiencies without non-immunologic phenotypes; combined immunodeficiencies with syndromic features; predominantly antibody deficiencies; diseases of immune dysregulation; congenital defects of phagocyte number, function, or both; defects of innate immunity; autoinflammatory disorders; complement deficiencies; and phenocopies of PID [2].

In the International Union of Immunological Societies Expert Committee for Primary Immunodeficiency classification [2], allergic manifestations are mentioned for 11 diseases (Table 1) and allergiclike manifestations for 6 diseases (Table 2). While mammalian sterile 20-like 1 (MST1) deficiency is included in this classification, its allergic manifestations were not listed (Table 3).

Clinical symptoms of dedicator of cytokinesis 8 (DOCK8) deficiency include atopic dermatitis, allergies, cutaneous viral infections, cutaneous staphylococcal abscesses, recurrent sinopulmonary infections, and malignancy $[8,9]$. Laboratory findings indicate elevated serum IgE levels, hypo-IgM, T cell lymphopenia, and eosinophilia [9]. The DOCK8 gene mutation was discovered in 2009 [10], allowing to isolate it as a separate nosological form, since it was previously known as autosomal recessive hyperIgE syndrome [11]. The authors reported about 21 patients with confirmed DOCK8 deficiency they had followed for 20 years [9]. Dermatitis in patients with DOCK8 deficiency occurred in 91\% of cases and was characterized by severe course. Substantial food and environmental allergies were registered in 71\% of DOCK8-deficient patients, while nearly $50 \%$ had asthma [9].

Another study reported a case of moderate atopic dermatitis, food allergy to cow's milk protein and hen eggs, and extensive molluscum contagiosum in a 3-year-old patient with DOCK8 deficiency [12]. 
Table 1: Primary immunodeficiencies associated with allergic manifestations (according to the classification from the international union of immunological societies expert committee for primary immunodeficiency)

\begin{tabular}{|c|c|c|c|}
\hline Disease & Inheritance & $\begin{array}{l}\text { Allergic } \\
\text { manifestations }\end{array}$ & Laboratory findings \\
\hline \multicolumn{4}{|c|}{ Combined immunodeficiencies } \\
\hline DOCK8 deficiency & AR & $\begin{array}{l}\text { Severe atopy, increased } \\
\text { IgE, hypereosinophilia. }\end{array}$ & $\begin{array}{l}\text { Decreased impaired } \\
\text { T-lymphocyte proliferation, } \\
\text { decreased, low CD } 27+\text { memory } \\
\text { B cells, low IgM, low NK cells } \\
\text { with impaired function }\end{array}$ \\
\hline Omenn syndrome & & $\begin{array}{l}\text { Erythroderma, } \\
\text { eosinophilia, increased } \\
\text { IgE. }\end{array}$ & $\begin{array}{l}\text { Restricted T cell repertoire, } \\
\text { and impaired function, B cells } \\
\text { normal or decreased, serum Ig } \\
\text { decreased }\end{array}$ \\
\hline \multicolumn{4}{|c|}{ Combined immunodeficiencies with associated or syndromic features } \\
\hline WAS & XL & $\begin{array}{l}\text { Eczema often increased } \\
\text { IgE. }\end{array}$ & $\begin{array}{l}\text { Progressive decrease, } \\
\text { abnormal lymphocyte } \\
\text { responses to anti-CD3, } \\
\text { decreased IgM: antibody to } \\
\text { polysaccharides particularly } \\
\text { decreased; often increased IgA }\end{array}$ \\
\hline WIP deficiency & AR & Eczema increased IgE. & $\begin{array}{l}\text { Reduced, defective lymphocyte } \\
\text { responses to anti-CD3, low } \\
\text { B cell. }\end{array}$ \\
\hline $\begin{array}{l}\text { AD- Hyper-IgE } \\
\text { syndrome } \\
\text { (Job's syndrome) }\end{array}$ & $\begin{array}{l}\text { AD Often de } \\
\text { novo defect }\end{array}$ & Eczema, elevated IgE; & $\begin{array}{l}\text { Normal Th-17 and T follicular } \\
\text { helper cells decreased, } \\
\text { switched and non-switched } \\
\text { memory B cells are reduced; } \\
\text { BAFF level increased, } \\
\text { specific antibody production } \\
\text { decreased }\end{array}$ \\
\hline Tyk2 deficiency & AR & Elevated IgE & $\begin{array}{l}\text { Multiple cytokine signaling } \\
\text { defect }\end{array}$ \\
\hline $\begin{array}{l}\text { Comel-Netherton } \\
\text { syndrome }\end{array}$ & AR & $\begin{array}{l}\text { Atopic diathesis, } \\
\text { elevated IgE. }\end{array}$ & $\begin{array}{l}\text { Switched and non-switched B } \\
\text { cells are reduced, elevated IgA, } \\
\text { antibody variably decreased }\end{array}$ \\
\hline STAT5b deficiency & AR & Eczema & Modestly decreased T-cell. \\
\hline
\end{tabular}

Predominantly antibody deficiencies Selective IgA deficiency Variable

Diseases of immune dysregulation

IPEX, immune XL

dysregulation,

polyendocrinopathy,

enteropathy X-linked

Autoinflammatory disorders

PLAID AD
May have allergies

Eczema, Elevated IgE.

Lack of (and/or
impaired function of)
CD4+CD25+FOXP3+regulatory
T cells (Tregs), elevated IgA

Cold urticaria

Mutations cause
Other clinical manifestations

Recurrent infections; extensive cutaneous viral and bacterial (staph.) infections, susceptibility to cancer

Adenopathies, hepatosplenomegaly

Thrombocytopenia with small platelets; lymphoma; autoimmune disease; IgA nephropathy; bacterial and viral infections.

Recurrent infections; thrombocytopenia. WAS-like phenotype.

Distinctive facial features (broad nasal bridge), osteoporosis, fractures, scoliosis, delay of shedding of primary teeth, hyperextensible joints, bacterial infections (skin and pulmonary abscesses, pneumatoceles) due to Staphylococcus aureus, candidiasis, aneurysm formation Susceptibility to intracellular bacteria (Mycobacteria, Salmonella), fungi, and viruses

Congenital ichthyosis, bamboo hair, increased bacterial infections, failure to thrive Growth-hormone insensitive dwarfism, dysmorphic features, lymphocytic interstitial pneumonitis, autoimmunity

Usually asymptomatic; may have recurrent infections; or autoimmune disease

Autoimmune enteropathy, early-onset diabetes, thyroiditis, hemolytic anemia, thrombocytopenia. activation of IL-1 pathway, hypogammaglobulinemia
Recurrent sinopulmonary infections, skin granuloma.

Data [2]. AD: Autosomal dominant, AR: Autosomal recessive, BAAF: B-cell activating factor, XL: X-linked, WAS: Wiskott-Aldrich syndrome, PLAID: PLC $\gamma 2$-associated antibody deficiency and immune dysregulation, DOCK8: Dedicator of cytokinesis 8, IL: Interleukin, Tyk2: Tyrosine kinase 2, IPEX: Immune dysregulation, polyendocrinopathy, enteropathy X-linked, FOXP3: Forkhead box protein 3

DOCK8 deficiency impacts immune cell function, migration, and affects innate and adaptive immune responses [13]. It also causes persistence of $\mathrm{B}$ cells in germinal centers, early T-cell death, and decreased natural killer cell cytotoxicity [14]. The median IgE levels in DOCK8 deficiency were $5201 \mathrm{IU}$, low IgM levels observed in $62 \%$ of patients, and lymphopenia in $20 \%$ of patients, mainly due to low $\mathrm{CD}^{+}$and $\mathrm{CD} 8^{+} \mathrm{T}$-cell number [15].

\section{Omenn syndrome}

Omenn syndrome is another severe combined immunodeficiency that is manifested by allergic symptoms. It is an autosomal recessive disease characterized by erythroderma, desquamation, alopecia, chronic diarrhea, failure to thrive, lymphadenopathy, eosinophilia, hepatosplenomegaly, and elevated serum IgE levels [16]. The disease is caused by mutations in the RAG1 or RAG2 genes [17]. Omenn syndrome is an inflammatory condition caused by multiple genetic abnormalities, which can significantly impair T-cell development in the thymus. It is a genetically heterogeneous condition, meaning that patients with similar phenotypes may have different underlying genetic defects. It was linked to mutations in ARTEMIS, ADA, ILRA2, ILRA7, CHD7, DNA ligase 4 , and other novel homozygous mutations $[18,19]$.

Omenn syndrome is associated with the virtual absence of $B$ cells, low IgG, IgA, and IgM levels [20]. The presence and expansion of oligoclonal autoreactive T cells lead to lymphocytosis [21]. Activated and antigen- 
Table 2: Primary immunodeficiencies associated with allergic-like manifestations

\begin{tabular}{|c|c|c|c|c|}
\hline Disease & Inheritance & $\begin{array}{l}\text { Allergic-like } \\
\text { manifestations }\end{array}$ & Laboratory findings & Other clinical manifestations \\
\hline \multicolumn{5}{|c|}{ Autoinflammatory disorders } \\
\hline MWS & $\mathrm{AD}$ & Urticaria & $\begin{array}{l}\text { Defect in cryopyrin, involved in } \\
\text { leukocyte apoptosis and NF- } \kappa B \text { signaling } \\
\text { and IL-1 processing }\end{array}$ & SNHL, amyloidosis \\
\hline FCAS & $\mathrm{AD}$ & $\begin{array}{l}\text { Non-pruritic } \\
\text { urticaria }\end{array}$ & $\begin{array}{l}\text { Defect in cryopyrin, involved in } \\
\text { leukocyte apoptosis and NF- } \kappa \text { B signaling } \\
\text { and IL-1 processing }\end{array}$ & $\begin{array}{l}\text { Arthritis, chills, fever, and } \\
\text { leukocytosis after exposure to cold }\end{array}$ \\
\hline NOMID or CINCA & $\mathrm{AD}$ & Neonatal onset rash & $\begin{array}{l}\text { Defect in cryopyrin, involved in } \\
\text { leukocyte apoptosis and NF- } \kappa \text { B signaling } \\
\text { and IL-1 processing }\end{array}$ & $\begin{array}{l}\text { Chronic meningitis, and arthropathy } \\
\text { with fever and inflammation }\end{array}$ \\
\hline TRAPS & $\mathrm{AD}$ & Rash & $\begin{array}{l}\text { Mutations of 55-kDa TNF receptor } \\
\text { leading to intracellular receptor } \\
\text { retention or decreased soluble cytokine } \\
\text { receptor available to bind TNF }\end{array}$ & $\begin{array}{l}\text { Recurrent fever, serositis, and ocular } \\
\text { or joint inflammation }\end{array}$ \\
\hline \multicolumn{5}{|l|}{ Complement deficiencies } \\
\hline C1 inhibitor deficiency & $\mathrm{AD}$ & HAE & $\begin{array}{l}\text { Spontaneous activation of the } \\
\text { complement pathway with consumption } \\
\text { of } \mathrm{C} 4 / \mathrm{C} 2 \text { spontaneous activation of } \\
\text { the contact system with generation of } \\
\text { bradykinin from high molecular weight } \\
\text { kininogen }\end{array}$ & \\
\hline
\end{tabular}

Data from [2]. MWS: Muckle-Wells syndrome, FCAS: Familial cold autoinflammatory syndrome, NOMID: Neonatal-onset multisystem inflammatory disease,

CINCA: Chronic infantile neurologic cutaneous and articular syndrome, TRAPS: TNF receptor-associated periodic syndrome, SNHL: Sensorineural hearing losses,

IL: Interleukin

Table 3: Other primary immunodeficiencies associated with allergic manifestations

\begin{tabular}{|c|c|c|c|c|}
\hline Disease & Inheritance & Allergic manifestations & Laboratory findings & Other clinical manifestations \\
\hline PGM3 deficiency & $\mathrm{AR}$ & $\begin{array}{l}\text { Atopic dermatitis, multiple } \\
\text { allergies, and asthma elevated IgE } \\
\text { level }\end{array}$ & $\begin{array}{l}\text { Cytopenias, mostly lymphopenia } \\
\text { and neutropenia. }\end{array}$ & $\begin{array}{l}\text { Recurrent infections, neurologic } \\
\text { abnormalities }\end{array}$ \\
\hline MST1 deficiency & $\mathrm{AR}$ & Eczematous dermatitis [59] & $\begin{array}{l}\text { Decreased/increased proportion } \\
\text { of terminal differentiated } \\
\text { effector memory cells (TEMRA), } \\
\text { low naïve } \mathrm{T} \text { cells, restricted } \mathrm{T} \\
\text { cell repertoire in the TEMRA } \\
\text { population, and impaired T cells } \\
\text { proliferation. }\end{array}$ & $\begin{array}{l}\text { Recurrentbacterial, viral, and candida } \\
\text { infections; intermittent neutropenia; } \\
\text { EBV-driven lymphoproliferation; } \\
\text { lymphoma; congenital heart disease, } \\
\text { autoimmune cytopenias; HPV } \\
\text { infection. }\end{array}$ \\
\hline
\end{tabular}

PGM3: Phosphoglucomutase 3, EBV: Epstein-Barr virus, HPV: Human papillomavirus

stimulated T helper $2\left(\mathrm{~T}_{\mathrm{H}} 2\right)$ cells produce high levels of interleukin 4 (IL-4) and IL-5. These cytokines caused eosinophilia and elevated IgE levels [17].

\section{Wiskott-Aldrich syndrome (WAS)}

Wiskott-Aldrich syndrome can also be manifested by eczema and increased IgE levels [2]. Eczema in patients with WAS is a feature of the clinical triad which also includes microthrombocytopenia and recurrent infections [22]. WAS is an X-linked disorder. The genes associated with WAS are on the short arm of the X chromosome (Xp11.22-p11.23). At present, there are more than 300 identified unique mutations resulting in WAS; this produces a wide variability of clinical symptoms [23]. The majority of the mutations are missense mutations, followed by nonsense, splice-site, and short deletion mutations.

Eczema was registered in $80 \%$ of the patients with WAS [22]. It is often identified during the $1^{\text {st }}$ month of life and fits the diagnostic criteria for atopic dermatitis. The eczema usually has widespread involvement, but primarily appears on the face, scalp, in the flexures, and diaper area. It is followed by progressive lichenification. Eczema can be complicated by secondary infections such as cellulitis and abscess and gets better with age [24]. Eczema can be associated with other IgE-mediated allergic diseases, such as urticaria, food allergies, and asthma.

Deficiency in the WAS protein (WASP)-interacting protein (WIP deficiency)

Deficiency in the WAS protein (WASP)-interacting protein (WIP deficiency) is a novel autosomal recessive PID [25]. Clinical features of WIP deficiency are similar to WAS, but the WAS sequence and mRNA levels are normal. WAS protein (WASP) cannot be detected in the cells of these patients. WASP is almost completely complexed with the WIP in T cells [26]. The main function of WIP is stabilization of WASP and prevention of its degradation [25]. Allergic manifestations in these patients are presented by eczema and increased IgE levels [2]. An eczematous rash appears in the $1^{\text {st }}$ day of life [26].

Hyper-IgE syndrome (Job's syndrome)

Hyper-IgE syndrome is an autosomal dominant disease (AD-HIES). Allergic manifestations of this disease are well known and well described $[2,7]$. The disease is characterized by eczema, recurrent bacterial infections (skin and pulmonary abscesses, pneumatoceles), mucocutaneous candidiasis, elevated serum IgE levels, and 
eosinophilia [2]. The severity of the disease can vary. AD-HIES is associated with heterozygous mutations of signal transducer and activator of transcription three genes (STAT3; 17q21.31) [27].

Neonatal rash is among first clinical features of this disorder. The skin barrier function in the AD-HIES patients is not impaired, in contrast with the AD patients that experience changes of skin barrier function [28].

AD-HIES affects not only the immune system but also connective tissue, skeleton, and dental development [29]. Distinctive facial features are a characteristic feature of this syndrome. Increased risk of autoimmune and lymphoproliferative diseases is also associated with this disease.

Increased IgE levels up to $2000 \mathrm{U} / \mathrm{ml}$ are common in patients with AD-HIES, often higher than $5000 \mathrm{U} / \mathrm{ml}$. Despite the high levels of IgE, the patients with AD-HIES suffer from a deficiency of allergic sensitization [27]; this can be explained by a normal skin barrier function and confirm its significance in the development of allergic sensitization.

In a study, the patients with STAT3 mutations experienced weakened allergic reactions, in particular, food allergies and anaphylaxis [30].

Since eczema can be among the early symptoms in patients with ADHIES, timely differentiation of HIES from atopic dermatitis is difficult, extremely important due to the differences in treatment [31].

\section{Human tyrosine kinase 2 (Tyk2) deficiency}

Human tyrosine kinase 2 (Tyk2) deficiency was initially registered in a Japanese patient as a syndrome with elevated IgE and with susceptibility to intracellular infections [2,32]. Another study reported a Turkish patient with Tyk2 deficiency without hyper-IgE syndrome [33]. Additional six patients from different countries with Tyk2 deficiency suffered from mycobacterial and viral infections without hyper-IgE syndrome [34]. Tyk2 deficiency leads to multiple cytokine signaling defects, first of all to impaired production of IFN- $\alpha / \beta$ and IL- 12 that causes susceptibility to intracellular infections [34]. The leukocytes and fibroblasts respond normally to IL-6, which can explain normal IgE levels in these patients. The main clinical manifestations of Tyk2 deficiency are mycobacterial and/or viral infections.

\section{Comel-Netherton syndrome}

Comel-Netherton syndrome is an autosomal recessive genodermatosis. Skin manifestations in these patients appear at birth or during the $1^{\text {st }}$ week of life. Typical ailments include congenital ichthyosiform erythroderma, atopic diathesis, and a hair-shaft abnormality known as trichorrhexis invaginata [35].

Skin inflammation, leading to scaling and exfoliation, and erythroderma, an atopic diathesis complicated by infections, sepsis, and dehydration are the disorders that can be life threatening. Dehydration caused by corneocyte barrier dysfunction can cause extensive metabolic abnormalities and hypernatremia [36].

Mutations of the both copies of serine protease inhibitor of kazal type 5 (SPINK5) gene cause Comel-Netherton syndrome [37]. SPINK5 products, such as lymphoepithelial kazal-type-related inhibitor (LEKTI), and tissue kallikreins (KLKs) balance serine proteases/inhibitors in skin and effect skin barrier function and desquamation [38]. SPINK5 mutations result in truncated LEKTI; thus, LEKTI in patients with Comel-Netherton syndrome can be of different length, depending on the location of mutations. Clinical manifestations correlate with LEKTI domain deficiency in patients with Comel-Netherton syndrome [38]. The studies have also proved that deregulated epidermal protease activity is linked to atopic dermatitis [39]. These studies point to new targets for treatment intervention.

Food allergy, especially to peanuts, eggs, and fish often persists in patients with Comel-Netherton syndrome. The majority of patients have an atopic predisposition, with a family history of asthma, atopic dermatitis or hay fever. Serum IgE levels are typically increased, sometimes exceeding 10,000 IU/mL [39]. Specific IgE antibodies to environmental and food allergens can be detected, and hypereosinophilia can be present in the patients.

\section{STAT5b deficiency}

STAT5b deficiency is an autosomal recessive disorder. It is characterized by short stature and recurrent pulmonary infections: Bacterial pneumonia or opportunistic infections (hemorrhagic Varicella, herpes zoster, and Pneumocystis jiroveci) [40-42]. Other clinical signs include dysmorphic features and a high-pitched voice. Short stature develops in these patients since STAT5b is involved in growth hormone induced signaling [41]. In addition, STAT5b is involved in the intracellular signaling cascade of IL-2 and IFN-gamma and causes immunodeficiency, typically $\mathrm{T}$ cell lymphopenia. Immune dysregulation is also manifested by eczema and autoimmunity.

\section{Selective IgA deficiency}

Selective IgA deficiency is the most common PID. The patients may be asymptomatic, have recurrent infections, or autoimmune diseases. Patients with selective IgA deficiency can also suffer from allergic disorders $[43,44]$. The incidence of allergic manifestations ranges from $13 \%$ [45] to $84 \%$ [46] of patients. There is a significant relationship between allergy incidence and patient's age: It is more commonly present among younger patients [45]. Other studies reported that low IgA levels are associated with atopic diseases not only in children but also in adults $[47,48]$. Allergy in patients with selective IgA deficiency is manifested by asthma, atopic dermatitis, allergic rhinitis/conjunctivitis, urticaria, drug allergy, and food allergy [46].

\section{Immune dysregulation, polyendocrinopathy, and enteropathy X-linked (IPEX) syndrome}

Immune dysregulation, polyendocrinopathy, and enteropathy X-linked (IPEX) syndrome is caused by inheritable mutations in the forkhead box protein 3 (FOXP3) gene and is characterized by the development of multiple autoimmune disorders [49]. FOXP3 Treg cells have inhibitory functions and are responsible for immune homeostasis and tolerance to self- and non-self-antigens [49]. Impaired function of FOXP3+ regulatory $\mathrm{T}$ cells leads to autoimmune disorders that usually are manifested by enteropathy, early-onset diabetes, thyroiditis, hemolytic anemia, and thrombocytopenia [2]. Severe diarrhea due to autoimmune enteropathy typically begins in the first few months of life and causes failure to thrive. Patients with IPEX syndrome frequently suffer from eczema. Autoimmune enteropathy and eczema are the main features of disease presence after 1 month of age [50]. They are often associated with increased IgE levels and eosinophilia in children with IPEX syndrome [51].

\section{PLC $\gamma$ 2-associated antibody deficiency and immune dysregulation (PLAID)}

PLC $\gamma 2$-associated antibody deficiency and immune dysregulation (PLAID) belongs to the group of autoinflammatory disorders and is characterized by cold urticaria, recurrent bacterial infections, autoimmunity, and skin granuloma development [52]. Cold urticaria in PLAID patients is common, and develops rapidly, within minutes after contact with cold; it resolves after warming up. Skin rash in cases of physical urticaria is caused by mast cell activation and mediator release $[53,54]$. Sometimes prolonged cold contact can cause anaphylaxis [52]. The patients frequently have a family history of atopy [53].

\section{Phosphoglucomutase 3 (PGM3) deficiency}

Phosphoglucomutase 3 (PGM3) deficiency was described in 2014 as an autosomal recessive disease associated with atopic dermatitis, recurrent infections, and increased IgE levels [55-57] (Table 3). Atopic dermatitis is a common manifestation; it was observed in all 17 registered patients with PGM3 deficiency $[55,56]$. Other allergic manifestations such as asthma and multiple allergies can also be present [57]. Neurologic abnormalities, such as developmental delay 
and low IQ ataxia, dysarthria, myoclonus, and sensorineural hearing loss, are common for these patients [57].

\section{MST1 deficiency}

Mammalian sterile 20-like (MST1) deficiency is an autosomal recessive disease, characterized by bacterial, viral, and candida cutaneous infections, and structural cardiac anomalies $[57,58]$. Eczema-like skin lesions beginning in the $1^{\text {st }}$ year of life and mild erythematous skin lesions were registered in 3 patients with MST1 deficiency from a single family [59].

\section{ALLERGIC-LIKE MANIFESTATIONS OF PID}

Some autoinflammatory disorders are characterized by rash, mostly of urticaria-like type (Table 3). This group includes cryopyrin-associated periodic syndromes (CAPS), represented by three diseases caused by a defect in the same gene CIAS1/NLRP3 coding for the protein cryopyrin (NALP3): Muckle-Wells syndrome (MWS), neonatal-onset multisystem inflammatory disease or chronic infantile neurologic, cutaneous, and articular syndrome (NOMID/CINCA), and familial cold autoinflammatory syndrome (FCAS) [60,61].

Rash in cases of CAPS is caused by a neutrophilic infiltrate in the dermis and is unrelated to mast cell degranulation [60]. Deficit of cryopyrin, involved in leukocyte apoptosis and NF- $\mathrm{KB}$ signaling and IL-1 processing, is detected in patients with CAPS [2]. All autoinflammatory conditions associated with periodic fever, joint pain, and other systemic manifestations can also be present. The severity and clinical signs vary for each of these diseases. NOMID/CINCA is the most severe condition, while FCAS is considered the mildest form [60].

MWS, also known as an urticaria-deafness-amyloidosis syndrome, is an autosomal dominant disease, which causes sensorineural deafness and recurrent hives, and can lead to amyloidosis. NOMID/CINCA is also characterized by progressive hearing loss, but in cases of MWS, it develops later. Cognitive and physical disability, bone and joint deformities, and short stature are evidenced in NOMID/CINCA [62]. Typically in FCAS, but less often in MWS, the symptoms are exacerbated by cold and are self-limited within 12-24 hs [61]. In NOMID/CINCA patients, the rash is present early: After birth or within the first few days or weeks of life. Typically, the rash is not irritating, but in some cases, it may be itchy [60].

Despite the differences in the pathogenesis of allergic rash and rash in patients with autoinflammatory disorders, in both instances, these manifestations look alike and require differential diagnosis. Such patients often come to see an allergist. FCAS can be considered as cold urticaria, which is an allergic reaction to cold temperatures that develops after a few minutes of cold exposure but is never associated with fever and joint pain.

TNF receptor-associated periodic syndrome (TRAPS) is caused by a mutation of the TNFRSF1A gene and characterized by episodic flares that last for 3 weeks or longer with fever, migrated rash, abdominal pain, joint pain, periorbital edema, and conjunctivitis [63]. Rash is one of the most frequent manifestations of TRAPS, and its occurrence varies from $55 \%$ [64] to $63 \%$ [63] of patients.

Blau syndrome (BS) is caused by the mutation in CARD15/NOD2 gene and characterized by early onset granulomatous arthritis, uveitis, and skin rash [65]. Clinical manifestations also include fever, malignant systemic and pulmonary hypertension, granulomatous large-vessel vasculitis and granulomatous inflammation of the liver, kidneys, and lungs.

Skin rash is an early symptom, usually the first manifestation, appearing in the $1^{\text {st }}$ year of life, often at the age of 1 month [66]. It is manifested by a symmetric dark red, slightly scaly, maculopapular, eczematoid-like or lichenoid-like rash with localization first on the face and spreading to the trunk and extremities; it resolves spontaneously [67].
C1 inhibitor deficiency, also called hereditary angioedema (HAE), is characterized by recurrent episodes of angioedema, without urticaria or pruritus [68]. The skin and mucosal tissues of upper respiratory and gastrointestinal tracts are often affected [69]. The swelling is selflimited, although when involves upper respiratory tract, especially larynx, it can lead to fatal asphyxiation.

Enormous production of bradykinin, a vasodilator mediator, causes the clinical manifestations of HAE [70]. In HAE, histamine and other mast cell mediators are not directly involved as they are in allergic and urticarial reactions, so antihistamines are not effective.

The above discussion proves that the variability of clinical manifestations in PID patients requires a multidisciplinary approach to their management [71] with the involvement of immunologists, allergists, and other specialists.

\section{TREATMENT APPROACHES}

Treatment approaches to the allergic manifestations in PID patients and allergic disorders are often different.

Common general treatment strategies of PID include antibiotics, intravenous or subcutaneous immunoglobulin (IVIG/SCIG), and hematopoietic stem cell transplantation (HSCT).

The treatment of allergy symptoms includes corticosteroids (topical, or inhaler, or nasal, or systemic) and/or local application of calcineurin inhibitors (tacrolimus and pimecrolimus) [72]. Although PID are often associated with viral, bacterial, and candida infections, it is a challenge to treat atopic dermatitis and other allergic manifestations by means of these drugs, considering their immunosuppressive action. These medications are not recommended for long-term use or treatment of large surface areas. Skin and other infections should be carefully examined. In cases of skin superinfection with Staphylococcus aureus in patients with PID and eczema, systemic antibiotics, and antiseptic arrangements are used just as in cases of general atopic dermatitis [73].

Long-Term use of emollients for the treatment of skin allergic manifestations is helpful in AD-HIES, WAS, Comel-Netherton syndrome, and other syndromes associated with eczema [74].

Patients with AD-HIES often require medication to control pruritus. Diphenhydramine or a longer-acting antihistamine such as loratadine, fexofenadine, desloratadine, or cetirizine can be used for this purpose [75].

HSCT is established as the treatment of choice in patients with combined immunodeficiencies (DOCK8 deficiency, Omenn syndrome, MST1 deficiency, WAS, and WIP deficiency) [76], and the main method of treatment in patients with IPEX syndrome $[77,78]$. Cutaneous improvement in the first 6 months after transplant was reported $[9,76]$. IVIG is the treatment of choice in Netherton's syndrome [79]. This therapy also results in relieving skin manifestations.

Immunosuppression with cyclosporine is recommended for dermatitis and eosinophilia treatment in patients with Omenn syndrome [80]. Interferon gamma can be used to control IL- 4 and IL-5 production in these patients.

Anti-inflammatory effect of Vitamin D3 supplementation has been proved in patients with asthma [81].

Gene therapy is being investigated to treat IPEX syndrome, Omenn syndrome, and WAS $[77,78,82]$.

Other approaches are used for the treatment of autoinflammatory disorders. Biologic agents that target interleukin-1 are effective for treating CAPS $[60,62]$. Anakinra is approved for patients with NOMID/ CINCA, rilonacept, and canakinumab - for patients with FCAS and MWS. 
Short-term corticosteroids, with or without NSAIDs, are effective for treating inflammatory attacks in patients with TRAPS [83]. Anakinra and canakinumab have been approved to be effective for treating these patients [84], and etanercept has been proved to be effective to some extent [85]. TNF inhibition with infliximab or adalimumab was studied for the treatment of Blau disease [86].

C1 inhibitor (C1-INH) concentrates or kallikrein inhibitor has been established as the treatment of choice in patients with HAE, Types I and II [87].

\section{CONCLUSIONS}

Allergic manifestations are one of the clinical signs of PID. They take place more often in patients with combined immunodeficiencies with or without associated or syndromic features.

Allergic manifestations in patients with PID usually are present in the $1^{\text {st }}$ year of life, they can be among the first symptoms of PID and are commonly manifested by eczema and increased IgG levels.

Often the skin barrier function is not impaired in patients with eczema and PID, although some diseases (Comel-Netherton syndrome) have a negative impact on skin barrier function.

There is usually no correlation between IgE levels and severity of allergic skin manifestation

Allergic-like manifestations in PID patients include urticarialike rash and angioedema. Urticaria-like rash is associated with autoinflammatory disorders, which are commonly accompanied by fever, and caused by a neutrophilic infiltrate in the dermis. Angioedema in HAE is caused by high production of bradykinin.

Early differentiation of allergic manifestations due to PID from atopic dermatitis and other atopic conditions is very difficult, although it is very important because it influences on the choice of treatment methods.

A multidisciplinary approach to the management of PID patients with the involvement of immunologists, allergists, and prescription of appropriate treatment improve the prognosis and quality of life of PID patients.

\section{ACKNOWLEDGMENT}

The author wishes to thank Jeffrey Modell Foundation for the support.

\section{AUTHOR'S CONTRIBUTIONS}

Concept, collection of data, writing the article, and critical review of the article has been carried out by Oksana Boyarchuk.

\section{CONFLICTS OF INTEREST}

The author hereby declares that there are no conflicts of interest in this research.

\section{REFERENCES}

1. Bousfiha AA, Jeddane L, Ailal F, Benhsaien I, Mahlaoui N, Casanova JL, et al. Primary immunodeficiency diseases worldwide: More common than generally thought. J Clin Immunol 2013;33:1-7.

2. Al-Herz W, Bousfiha A, Casanova JL, Chatila T, Conley ME, Cunningham-Rundles $\mathrm{C}$, et al. Primary immunodeficiency diseases: An update on the classification from the international union of immunological societies expert committee for primary immunodeficiency. Front Immunol 2014;5:162.

3. Modell V, Orange JS, Quinn J, Modell F. Global report on primary immunodeficiencies: 2018 update from the Jeffrey Modell centers network on disease classification, regional trends, treatment modalities, and physician reported outcomes. Immunol Res 2018; Doi: 10.1007/ s12026-018-8996-5.
4. Kumar Y, Bhatia A. Immunopathogenesis of allergic disorders: Current concepts. Expert Rev Clin Immunol 2013;9:211-26.

5. Fedortsiv O, Brozek GM, Luchyshyn N, Kubey I, Lawson JA, Rennie DC, et al. Prevalence of childhood asthma, rhinitis, and eczema in the Ternopil region of Ukraine - results of BUPAS study. Adv Med Sci 2012;57:282-9.

6. Boyarchuk O, Lewandowicz-Uszynska A, Kinash M, Haliyash N, Sahal I, Kovalchuk T. Physicians' awareness concerning primary immunodeficiencies in Ternopil region, Ukraine. Pediatr Pol 2018;93:221-8.

7. Lehman H. Skin manifestations of primary immune deficiency. Clin Rev Allergy Immunol 2014;46:112-9.

8. Zhang Q, Davis JC, Dove CG, Su HC. Genetic, clinical, and laboratory markers for DOCK8 immunodeficiency syndrome. Dis Markers 2010;29:131-9.

9. Chu EY, Freeman AF, Jing H, Cowen EW, Davis J, Su HC, et al. Cutaneous manifestations of DOCK 8 deficiency syndrome. Arch Dermatol 2012;148:79-84.

10. Zhang Q, Davis JC, Lamborn IT, Freeman AF, Jing H, Favreau AJ, et al. Combined immunodeficiency associated with DOCK8 mutations. N Engl J Med 2009;361:2046-55.

11. Su HC. Dedicator of cytokinesis 8 (DOCK8) deficiency. Curr Opin Allergy Clin Immunol 2010;10:515-20.

12. Purcell C, Cant A, Irvine AD. DOCK 8 primary immunodeficiency syndrome. Lancet 2015;386:982.

13. Biggs CM, Keles S, Chatila TA. DOCK8 deficiency: Insights into pathophysiology, clinical features and management. Clin Immunol 2017;181:75-82.

14. Dimitrova D, Freeman AF. Current status of dedicator of cytokinesisassociated immunodeficiency: DOCK8 and DOCK2. Dermatol Clin 2017;35:11-9.

15. Engelhardt KR, Gertz ME, Keles S, Schäffer AA, Sigmund EC, Glocker C, et al. The extended clinical phenotype of 64 patients with dedicator of cytokinesis 8 deficiency. J Allergy Clin Immunol 2015;136:402-12.

16. Zhang ZY, Zhao XD, Jiang LP, Liu EM, Cui YX, Wang M, et al. Clinical characteristics and molecular analysis of three Chinese children with Omenn syndrome. Pediatr Allergy Immunol 2011;22:482-7.

17. Wang YQ, Cui YX, Feng J. Clinical phenotype and gene diagnostic analysis of Omenn syndrome. Zhonghua Er Ke Za Zhi 2013;51:64-8.

18. Liao CY, Yu HW, Cheng CN, Chen JS, Lin CW, Chen PC, et al. A novel pathogenic mutation on interleukin-7 receptor leading to severe combined immunodeficiency identified with newborn screening and whole exome sequencing. J Microbiol Immunol Infect 2018:2018:S1182-684

19. Gruber TA, Shah AJ, Hernandez M, Crooks GM, Abdel-Azim $\mathrm{H}$, Gupta $\mathrm{S}$, et al. Clinical and genetic heterogeneity in Omenn syndrome and severe combined immune deficiency. Pediatr Transplant 2009; $13: 244-50$.

20. Couëdel C, Roman C, Jones A, Vezzoni P, Villa A, Cortes P, et al. Analysis of mutations from SCID and Omenn syndrome patients reveals the central role of the rag2 PHD domain in regulating $\mathrm{V}(\mathrm{D}) \mathrm{J}$ recombination. J Clin Invest 2010;120:1337-44

21. Zafar R, Ver Heul A, Beigelman A, Bednarski JJ, Bayliss SJ, Dehner LP, et al. Omenn syndrome presenting with striking erythroderma and extreme lymphocytosis in a newborn. Pediatr Dermatol 2017;34:e37-9

22. Sullivan KE, Mullen CA, Blaese RM, Winkelstein JA A multiinstitutional survey of the Wiskott-Aldrich syndrome. J Pediatr 1994; $125: 876-85$.

23. Bastida JM, Del Rey M, Revilla N, Benito R, Perez-Andrés M, González B, et al. Wiskott-Aldrich syndrome in a child presenting with macrothrombocytopenia. Platelets 2017;28:417-20.

24. Ochs HD, Thrasher AJ. The Wiskott-Aldrich syndrome. J Allergy Clin Immunol 2006;117:725-38

25. Lanzi G, Moratto D, Vairo D, Masneri S, Delmonte O, Paganini T, et al. A novel primary human immunodeficiency due to deficiency in the WASP-interacting protein WIP. J Exp Med 2012;209:29-34.

26. de la Fuente MA, Sasahara Y, Calamito M, Antón IM, Elkhal A, Gallego $\mathrm{MD}$, et al. WIP is a chaperone for Wiskott-Aldrich syndrome protein (WASP). Proc Natl Acad Sci U S A 2007;104:926-31.

27. Boos AC, Hagl B, Schlesinger A, Halm BE, Ballenberger N, Pinarci M, et al. Atopic dermatitis, STAT3- and DOCK8-hyper-IgE syndromes differ in IgE-based sensitization pattern. Allergy 2014;69:943-53.

28. Mócsai G, Gáspár K, Dajnoki Z, Tóth B, Gyimesi E, Bíró T, et al. Investigation of skin barrier functions and allergic sensitization in patients with hyper-IgE syndrome. J Clin Immunol 2015;35:681-8. 
29. Wu J, Chen J, Tian ZQ, Zhang H, Gong RL, Chen TX, et al. Clinical manifestations and genetic analysis of 17 patients with autosomal dominant hyper-IgE syndrome in Mainland China: New reports and a literature review. J Clin Immunol 2017;37:166-79.

30. Siegel AM, Stone KD, Cruse G, Lawrence MG, Olivera A, Jung MY, et al. Diminished allergic disease in patients with STAT3 mutations reveals a role for STAT3 signaling in mast cell degranulation. J Allergy Clin Immunol 2013;132:1388-96.

31. Hagl B, Heinz V, Schlesinger A, Spielberger BD, Sawalle-Belohradsky J, Senn-Rauh M, et al. Key findings to expedite the diagnosis of hyper$\mathrm{IgE}$ syndromes in infants and young children. Pediatr Allergy Immunol 2016;27:177-84.

32. Minegishi Y, Saito M, Morio T, Watanabe K, Agematsu K, Tsuchiya S, et al. Human tyrosine kinase 2 deficiency reveals its requisite roles in multiple cytokine signals involved in innate and acquired immunity. Immunity 2006;25:745-55.

33. Kilic SS, Hacimustafaoglu M, Boisson-Dupuis S, Kreins AY, Grant AV, Abel L, et al. A patient with tyrosine kinase 2 deficiency without hyperIgE syndrome. J Pediatr 2012;160:1055-7.

34. Kreins AY, Ciancanelli MJ, Okada S, Kong XF, Ramírez-Alejo N, Kilic SS, et al. Human TYK2 deficiency: Mycobacterial and viral infections without hyper-IgE syndrome. J Exp Med 2015;212:1641-62.

35. Bitoun E, Chavanas S, Irvine AD, Lonie L, Bodemer C, Paradisi M. Netherton syndrome: Disease expression and spectrum of SPINK5 mutations in 21 families. J Invest Dermatol 2002;118:352-61.

36. Stoll C, Alembik Y, Tchomakov D, Messer J, Heid E, Boehm N, et al. Severe hypernatremic dehydration in an infant with Netherton syndrome. Genet Couns 2001;12:237-43.

37. Wang S, Olt S, Schoefmann N, Stuetz A, Winiski A, Wolff-Winiski B, et al. SPINK5 knockdown in organotypic human skin culture as a model system for Netherton syndrome: Effect of genetic inhibition of serine proteases kallikrein 5 and kallikrein 7. Exp Dermatol 2014;23:524-6.

38. Komatsu N, Saijoh K, Jayakumar A, Clayman GL, Tohyama M, Suga Y, et al. Correlation between SPINK5 gene mutations and clinical manifestations in Netherton syndrome patients. J Invest Dermatol 2008; $128: 1148-59$

39. Hovnanian A. Netherton syndrome: Skin inflammation and allergy by loss of protease inhibition. Cell Tissue Res 2013;351:289-300.

40. Hwa V. STAT5B deficiency: Impacts on human growth and immunity. Growth Horm IGF Res 2016;28:16-20.

41. Hwa V, Nadeau K, Wit JM, Rosenfeld RG. STAT5b deficiency: Lessons from STAT5b gene mutations. Best Pract Res Clin Endocrinol Metab 2011;25:61-75.

42. Klammt J, Neumann D, Gevers EF, Andrew SF, Schwartz ID, Rockstroh D, et al. Dominant-negative STAT5B mutations cause growth hormone insensitivity with short stature and mild immune dysregulation. Nat Commun 2018;9:2105.

43. Yel L. Selective igA deficiency. J Clin Immunol 2010;30:10-6.

44. Janzi M, Kull I, Sjöberg R, Wan J, Melén E, Bayat N, et al. Selective IgA deficiency in early life: Association to infections and allergic diseases during childhood. Clin Immunol 2009;133:78-85.

45. Edwards E, Razvi S, Cunningham-Rundles C. IgA deficiency: Clinical correlates and responses to pneumococcal vaccine. Clin Immunol 2004; 111:93-7

46. Aghamohammadi A, Cheraghi T, Gharagozlou M, Movahedi M, Rezaei N, Yeganeh M, et al. IgA deficiency: Correlation between clinical and immunological phenotypes. J Clin Immunol 2009;29:130-6.

47. Balzar S, Strand M, Nakano T, Wenzel SE. Subtle immunodeficiency in severe asthma: IgA and $\operatorname{IgG} 2$ correlate with lung function and symptoms. Int Arch Allergy Immunol 2006;140:96-102.

48. Kim WJ, Choi IS, Kim CS, Lee JH, Kang HW. Relationship between serum IgA level and allergy/asthma. Korean J Intern Med 2017:32:137-45.

49. Bin Dhuban K, Piccirillo CA. The immunological and genetic basis of immune dysregulation, polyendocrinopathy, enteropathy, X-linked syndrome. Curr Opin Allergy Clin Immunol 2015;15:525-32.

50. Barzaghi F, Hernandez LC, Neven B, Ricci S, Kucuk ZY, Bleesing JJ, et al. Long-term follow-up of IPEX syndrome patients after different therapeutic strategies: An international multicenter retrospective study. J Allergy Clin Immunol 2018;141:1036-49.

51. Gambineri E, Perroni L, Passerini L, Bianchi L, Doglioni C, Meschi F, et al. Clinical and molecular profile of a new series of patients with immune dysregulation, polyendocrinopathy, enteropathy, $\mathrm{X}$-linked syndrome: Inconsistent correlation between forkhead box protein 3 expression and disease severity. J Allergy Clin Immunol 2008;122:1105-120.

52. Milner JD. PLAID: A Syndrome of complex patterns of disease and unique phenotypes. J Clin Immunol 2015;35:527-30

53. Abajian M, Młynek A, Maurer M. Physical urticaria. Curr Allergy Asthma Rep 2012;12:281-7.

54. Ombrello MJ, Remmers EF, Sun G, Freeman AF, Datta S, Torabi-Parizi P, et al. Cold urticaria, immunodeficiency, and autoimmunity related to PLCG2 deletions. N Eng1 J Med 2012;366:330-8.

55. Sassi A, Lazaroski S, Wu G, Haslam SM, Fliegauf M, Mellouli F, et al. Hypomorphic homozygous mutations in phosphoglucomutase 3 (PGM3) impair immunity and increase serum IgE levels. J Allergy Clin Immunol 2014;133:1410-9, 1419.e1-13.

56. Zhang Y, Yu X, Ichikawa M, Lyons JJ, Datta S, Lamborn IT, et al. Autosomal recessive phosphoglucomutase 3 (PGM3) mutations link glycosylation defects to atopy, immune deficiency, autoimmunity, and neurocognitive impairment. J Allergy Clin Immunol 2014;133:1400-9, 1409.e1-5.

57. Pichard DC, Freeman AF, Cowen EW. Primary immunodeficiency update: Part I. Syndromes associated with eczematous dermatitis. J Am Acad Dermatol 2015;73:355-64

58. Abdollahpour H, Appaswamy G, Kotlarz D, Diestelhorst J, Beier R, Schäffer AA, et al. The phenotype of human STK4 deficiency. Blood 2012;119:3450-7.

59. Nehme NT, Schmid JP, Debeurme F, André-Schmutz I, Lim A, Nitschke $\mathrm{P}$, et al. MST1 mutations in autosomal recessive primary immunodeficiency characterized by defective naive T-cell survival. Blood 2012;119:3458-68.

60. Goldbach-Mansky R. Current status of understanding the pathogenesis and management of patients with NOMID/CINCA. Curr Rheumatol Rep 2011;13:123-31.

61. Hoffman HM, Mueller JL, Broide DH, Wanderer AA, Kolodner RD. Mutation of a new gene encoding a putative pyrin-like protein causes familial cold autoinflammatory syndrome and Muckle-Wells syndrome. Nat Genet 2001;29:301-5.

62. Goldbach-Mansky R, Dailey NJ, Canna SW, Gelabert A, Jones J, Rubin BI, et al. Neonatal-onset multisystem inflammatory disease responsive to interleukin-1beta inhibition. N Engl J Med 2006;355:581-92.

63. Lachmann HJ, Papa R, Gerhold K, Obici L, Touitou I, Cantarini L, et al. The phenotype of TNF receptor-associated autoinflammatory syndrome (TRAPS) at presentation: A series of 158 cases from the euro fever/ EUROTRAPS international registry. Ann Rheum Dis 2014;73:2160-7.

64. Ueda N, Ida H, Washio M, Miyahara H, Tokunaga S, Tanaka F, et al. Clinical and genetic features of patients with TNFRSF1A variants in Japan: Findings of a nationwide survey. Arthritis Rheumatol 2016;68:2760-71

65. Caso F, Galozzi P, Costa L, Sfriso P, Cantarini L, Punzi L, et al. Autoinflammatory granulomatous diseases: From Blau syndrome and early-onset sarcoidosis to NOD2-mediated disease and crohn's disease. RMD Open 2015; 1:e000097.

66. Rosé CD, Pans S, Casteels I, Anton J, Bader-Meunier B, Brissaud P, et al. Blau syndrome: Cross-sectional data from a multicentre study of clinical, radiological and functional outcomes. Rheumatology (Oxford) 2015;54:1008-16.

67. Wouters CH, Maes A, Foley KP, Bertin J, Rose CD. Blau syndrome, the prototypic auto-inflammatory granulomatous disease. Pediatr Rheumatol Online J 2014;12:33.

68. Pappalardo E, Cicardi M, Duponchel C, Carugati A, Choquet S, Agostoni A, et al. Frequent de novo mutations and exon deletions in the Clinhibitor gene of patients with angioedema. J Allergy Clin Immunol 2000;106:1147-54

69. Cicardi M, Aberer W, Banerji A, Bas M, Bernstein JA, Bork K, et al. Classification, diagnosis, and approach to treatment for angioedema: Consensus report from the hereditary angioedema international working group. Allergy 2014;69:602-16.

70. Bork K, Frank J, Grundt B, Schlattmann P, Nussberger J, Kreuz W, et al. Treatment of acute edema attacks in hereditary angioedema with a bradykinin receptor-2 antagonist (Icatibant). J Allergy Clin Immunol 2007;119:1497-503.

71. Boyarchuk O, Volyanska L, Dmytrash L. Clinical variability of chromosome 22q11.2 deletion syndrome. Cent Eur J Immunol 2017;42:412-7

72. Appalasamy JR, Sariff A. A survey of drug-related-problems among patients treated for allergy symptoms in community pharmacies at Negeri Sembilan, Malaysia. Int J Pharm Pharm Sci 2014;6:313-6.

73. Bath-Hextall FJ, Birnie AJ, Ravenscroft JC, Williams HC. Interventions to reduce Staphylococcus aureus in the management of atopic eczema: An updated cochrane review. Br J Dermatol 2010;163:12-26.

74. Peacocke M, Siminovitch KA. Wiskott-Aldrich syndrome: New molecular 
and biochemical insights. J Am Acad Dermatol 1992;27:507-19.

75. Bonilla FA, Bernstein IL, Khan DA, Ballas ZK, Chinen J, Frank MM, et al. Practice parameter for the diagnosis and management of primary immunodeficiency. Ann Allergy Asthma Immunol 2005;94:S1-63.

76. Ghosh S, Schuster FR, Adams O, Babor F, Borkhardt A, Comoli P, et al. Haploidentical stem cell transplantation in DOCK8 deficiency - Successful control of pre-existing severe viremia with a TCRaß/CD19-depleted graft and antiviral treatment. Clin Immunol 2014;152:111-4.

77. Passerini L, Santoni de Sio FR, Porteus MH, Bacchetta R. Gene/cell therapy approaches for immune dysregulation polyendocrinopathy enteropathy X-linked syndrome. Curr Gene Ther 2014;14:422-8.

78. Horino S, Sasahara Y, Sato M, Niizuma H, Kumaki S, Abukawa D, et al. Selective expansion of donor-derived regulatory $\mathrm{T}$ cells after allogeneic bone marrow transplantation in a patient with IPEX syndrome. Pediatr Transplant 2014;18:E25-30.

79. Renner ED, Hartl D, Rylaarsdam S, Young ML, Monaco-Shawver L, Kleiner $\mathrm{G}$, et al. Comèl-Netherton syndrome defined as primary immunodeficiency. J Allergy Clin Immunol 2009;124:536-43.

80. Caglayan Sozmen S, Isik S, Arikan Ayyildiz Z, Yildiz K, Cakır Y, Ozer E, et al. Cyclosporin treatment improves skin findings in Omenn syndrome. Pediatr Dermatol 2015;32:e54-7.

81. Abbas RS, Abdulridha MK, Shafek MA. Clinical evaluation of the potential anti-inflammatory effect of Vitamin D3 adjuvant therapy for chronic asthma in Iraqi patients. Int J Pharm Pharm Sci 2017;9:139-44.

82. Capo V, Castiello MC, Fontana E, Penna S, Bosticardo M, Draghici E, et al. Efficacy of lentivirus-mediated gene therapy in an Omenn syndrome recombination-activating gene 2 mouse model is not hindered by inflammation and immune dysregulation. J Allergy Clin Immunol 2018;142:928-41.

83. Ter Haar NM, Oswald M, Jeyaratnam J, Anton J, Barron KS, Brogan PA, et al. Recommendations for the management of autoinflammatory diseases. Ann Rheum Dis 2015;74:1636-44.

84. Gattorno M, Obici L, Cattalini M, Tormey V, Abrams K, Davis N, et al. Canakinumab treatment for patients with active recurrent or chronic TNF receptor-associated periodic syndrome (TRAPS): An open-label, phase II study. Ann Rheum Dis 2017;76:173-8.

85. Quillinan N, Mannion G, Mohammad A, Coughlan R, Dickie LJ, McDermott MF, et al. Failure of sustained response to etanercept and refractoriness to anakinra in patients with T50M TNF-receptorassociated periodic syndrome. Ann Rheum Dis 2011;70:1692-3.

86. Rammel J, Rosillo P, Vogel T, de Guzman M. Treatment of blau syndrome with biologic therapy: A single center case series of seven patients over two decades. Arthritis Rheum 2017;69 Suppl 4:80.

87. Zuraw BL, Busse PJ, White M, Jacobs J, Lumry W, Baker J, et al. Nanofiltered $\mathrm{C} 1$ inhibitor concentrate for treatment of hereditary angioedema. N Engl J Med 2010;363:513-22. 